\title{
A CASE STUDY OF FORMS AND SYMPTOMS OF CULTURE SHOCKS OF THE FOREIGN STUDENTS IN YOGYAKARTA
}

Intan Pradita

Islamic University of Indonesia

\begin{abstract}
Entering multicultural society involves two participants, foreigners and natives. Due to globalization issues, multicultural society are required to have not only a good language competence but also a deep understanding of culture and religious belief. A long process of understading each other force the praticipants to have a good adaptation, which reveals some problems, such as culture shocks and alienation.Moreover, these problems hang on both parties. Therefore, analyzing the symptoms and forms of culture shocks is interesting leading to the way to overcome. One sample of multicultural society grows in Yogyakarta. The number of foreigners aim to study Bahasa Indonesia deal with Yogyakarta people as native Javanese are unique for their inquiries and comments towards Javanese culture. This research shows that although some forms of culture shocks strongly happened, they finally could manage to adapt with some strict normative rules and make friends to Indonesian people.
\end{abstract}

Keywords: intercultural communication, cultural shocks

\section{BACKGROUND}

Culture is one of the most important issues that attracts worldviews. People of all over the world finally realize that they are different, thus it is necessary to understand each other. One of the way of understanding is through culture. People live with culture which includes their religion, belief, custom and their habit. Growing separately, without having good understanding will create conflicts from those parties who do not have something that is called as tollerance. 
What makes problematic towards this issue is, understanding the diversity of culture is uneasy. It requires quite long process of studying and sometimes forces some people to realy change their belief when they argue one another. The way of understanding certain differences is a must when people live in multicultural society.

One of the place that provides a good space of muticultural society in Indonesia is Yogyakarta. Being well-known of its friendly and warm welcome, Yogyakarta is placed as the second favorable visited place in Indonesia after Bali. Some foreigners step their foots in Yogyakarta for tourism issues, but others may have different motivation. This paper is aimed at revealing what are the forms of culture shocks that are obtained by the the foreign students in Yogyakarta and how they deal with that. The foreign students are chosen in this study based on two reasons. That they have a more fix schedule and they can observe Yogyakarta and Indonesia academically through teaching learning process in their univeristies. There are three the foreign students chosen as the respondents to be interviewed in this study. Those are Asnate Strike from Latvia, Europe, Paramvir Sainik from India, South Asia, and Yolanda Luluaki from Papua New Guenia.

\section{PROBLEMS IDENTIFICATION}

Some problems of cultural understanding happens almost everyday when the foreign students attend the class and socialize with their circumstances dealing with cultural understanding. There are some kinds of responses come from the the foreign students whenever something bad accidentaly happens. Their Indonesian friends are placed as the front liners to capture these responses, both in the form of hate speech, constructive criticism, or even in the form of high understanding. Some students are failed to deal with their culture shock and some others are success to make friends with all types of people who bring their cultural identity.This study aims to reveal the forms and symptoms of culture shocks happened to the the foreign students in Yogyakarta and how the the foreign students deal with the culture shocks happened to them. 


\section{SOCIOLINGUISTICS}

Sociolinguistics is the study of how language is used in society. Chaika (1982: 2) defines sociolinguistics as "the study of how people use language in social interaction." As an empirical study, sociolinguistics has great significance in combining linguistic and sociological theories and methods. Coulmas (2003: 563) states that this subject attaches great significance to the variability of language as well as to the multiplicity of languages an language forms in a given society.

Furthermore, Wardaugh (2006: 13) also stresses that through studying language, people are able to discover how social structure is understood in society. As a result, society and language become the main focus in the investigation. Since sociolinguistics deals with how language is used in society, it gives contribution in analysing intercultural communication. According to Trudgill (2006: 2539), sociolinguistics provides the frameworks needed for indepth analysis of intercultural communication. It plays a major role in focusing on the interaction between members of those cultural groups; what really happens and what may go wrong in the communication process since it describes the interactional context as well as background factors affecting the communication across culture.

\section{INTERCULTURAL COMMUNICATION}

Intercultural communication is a kind of communication that occurs whenever two or more people from different cultures interact (Hybels and Weaver II, 1998: 21). Similarly, Jandt (2004: 39) says that "Intercultural communication refers to facetoface interactions among people of diverse cultures." Thus, it is a sequence of verbal exchanges in which the cultural differences may have some influences to the effectiveness of the communication. As a result, anticipating potential crosscultural misunderstandings is needed to make a satisfactory encounter.

Intercultural communication is likely to happen in multicultural society where the members of this society consist of different cultural backgrounds. Chandra \& Mahajan (2007: 3) say that a multicultural society is one with a plurality of cultures either in the form that the society has a plurality of a welldefined cultural communities, or that its members might be drawn to different bodies of ideas and subscribe to them in different degrees without forming distinct communities. In other words, members of a multicultural society are not all agreed 
on common ways of understanding and organizing their lives.

It is undeniable that culture become the main important thing in intercultural communication. Culture is the context, the environment in which the communication takes place and which helps to define the communication. The definition of culture according to Singer (1998: 5) is a pattern of learned, grouprelated perceptions including both verbal and nonverbal language, attitudes, values, belief and disbelief systems as well as behaviours that is accepted and expected by an identity group. Every culture has its own worldview, its own way of perceiving self, and its own system of social organization. Knowing each of these helps people assign meaning to the communicated symbols which are critical to the success of the communication.

As cultures in the world differ from one another, the communication practices and behaviours of people will inevitably vary as a result of their different perceptions of the world. Thus, it indicates a hint how difficult communication can be if the participants of a communication are in different contexts and share different symbols. This is in line with what Wardhaugh (2006: 307) proposes that people tend to rely heavily on their cultural background in talking and interpreting the talk of others. Therefore, this can create difficulties when people communicating with others who are complete strangers or come from quite different cultural backgrounds. The cultural differences can affect the process of the interpretation of speakers' intentions or meanings. As a result, some barriers emerge to impede this communication. on common ways of understanding and organizing their lives.

In order to gain the effectiveness in intercultural communication, Pinto (2000: 15) states that there are three elements needed for intercultural communication, those are:

a. Intercultural perspective

Individuals involved in intercultural communication must acknowledge the existence of cultural differences and also recognize how cultural differences affect thoughts, feelings, and actions.

b. Double perspective

A double perspective in intercultural situations entail looking at the situation from the viewpoint of one's own culture as well as from the other's person culture. 
c. Three step method

1) getting to know one's own norms, values, and behavioural codes. By taking this step, the individual learns about and becomes aware of behaviour and communication from his own perspective.

2) getting to know the norms, the values, and the behavioural codes of the other party. Through this, the individual is aware of behaviour and communication from the other party's perspective.

3) determining how to deal with observed differences in norms, values, and behavioural codes in the given situation. By taking this step, the individual transforms into a multicultural person, i.e. one who respects cultures and has tolerance for differences.

In addition, Jandt (2004: 48) states that to get the effective intercultural communication, the participants involved must have:

a. personality strength; the individuals have strong sense of self and are socially relaxed,

b. communication skills either verbal or nonverbal,

c. psychological adjustment or the ability to adapt to new situations, and

d. cultural awareness or understanding how people of different culture think and act.

In intercultural communication, people must be aware of the potential for various misunderstandings and want to avoid them. However, serious misunderstandings and even conflicts can occur. Even though people are trying to avoid problems, they are still making judgments as they are communicating. This what makes prejudice as a term referred to making judgments about individuals emerge to impede communication.

\section{CULTURE SHOCK}

\section{Definition of Culture Shock}

Jandt (2004: 72) explains that culture shock is a phrase that was popularized by anthropologist Kalvero Oberg (1960) to describe the feelings of disorientation and anxiety that many people experience for a period of time while living in a foreign country. It results from an awareness that one's basic assumptions about life and one's familiar ways of behaving are no longer appropriate or functional. 
Whether an individual enters a host culture as a sojourner or as an immigrant, Furham \& Bochner (1986) says that culture shock is the first likely response. Unless we are prepared to function in the new culture, the situation can be highly stressful. This form of stress and anxiety is called culture shock.

\section{Forms of Culture Shock (Barriers)}

\section{a) Anxiety}

Anxiety is when a person is anxious because of not knowing what he/she is expected to do (Jandt, 2004: 74). It is only natural to focus on that feeling and not be totally present in the communication transaction. For example, a person may have experienced anxiety on a new college campus or in a new job. The person may focus so much of his/her attention on that feeling that $\mathrm{s} /$ he makes common mistakes and appear awkward to others.

\section{b) Sterotypes}

According to Jandt (2004:93) stereotype is the broader term commonly used to refer to negative and positive judgments made about individuals based on any observable or believed group membership. Another definition of stereotype is from Greenwald, Banaji, Rudman, Farnham, Nasek, Mellot (2002:5) that a stereotype is the association of a social group concept with one or more (nonvalence) attribute concepts).

Stereotype according to a psycholog (Nisbett,1980) in Jandt (2004:94) as mistakes our brains make in the perception of other people that are similar to those mistakes our brain make in the perception of visual illusion. From all definitions provided it can be assumed that stereotype is a term used to utter the positive or negative perception to other people or other groups based on a deep-whole observation.

\section{c) Prejudice}

The root word of prejudice is "prejudge". This word then refers to prejudgment that is making decision before becoming aware of the relevant facts of a case or event. Initially, prejudice means prejudgment but then it is widely used to refer to any hostile attitude towards people based on their race, sex, ethnicity, sexual orientation, age, and religion. Jandt (2004: 93) relates prejudice to the irrational dislike, suspicion or hatred of a particular group, race, religion, or sexual orientation. Similarly, Samovar and Porter (1991: 281) state that prejudice is "the unfair, biased, or 
intolerant attitudes or opinions towards another person or group simply because they belong to a specific religion, race, nationality, or another group." Therefore, these negative evaluations and attitudes can create problems in an interaction as people generally need a positive selfimage.

Prejudice influences the way people communicate to each other or the way they speak and use language. In other words, prejudice makes people employ certain style of speech in communicating to each other particularly when communication involves participants from different cultural backgrounds. Thus, language is employed by prejudiced people to reflect negative social attitudes towards the targets.

\section{Symptoms of Culture Shock}

Jandt (2004: 322) explains that the symptoms of culture shocks are pervasive and vary in intensity, duration, and severity among individuals. Individuals can experience both physical and psychological symptoms.

Physical symptoms are overconcerned about cleanliness of food, bedding, and dishes; extreme stress on health and safety; fear of physical contact with anyone in the new country; great concern over minor pains and skin eruptions; craving "home cooking"; use of alcohol and drugs, and a decine in work quality.

Psychological symptoms are insomnia, fatigue, isolation, and loneliness, disorientation, frustation, criticism of the new country, nerveousness, self-doubts, irritability, depression, anger, and emotional and intellectual withdrawal.

\section{FORMS AND SYMPTOMS OF CULTURE SHOCKS FACED BY THE FOREIGN STUDENTS IN YOGYAKARTA}

There are two forms of culture shock that are experienced by the foreign students in Yogyakarta. The first is about anxiety. As explained before that anxiety refers to someone who do not know what she should do in the new place. The form of anxiety also refers to someone who focus too much on something until her atitude will be awkward or mistaken. The form of anxiety is presented in the interview.

It is shown by their statement to answer the question on what comes to their mind before going to Yogyakarta or in Indonesia. From the interview, Asnate who is in this researh chosen as the representative of European student said that : 
I: So, what comes to your mind before you go to Yogyakarta? The prediction...

A: Nothing actually. I was just a bit scared because it's my first time to Indonesia and it's a moeslem country. So there should be (Asnate smiled) --(paused for a moment because I was trying to translate the meaning of the smile)

\section{I: What do you afraid of?}

A: Mmm...that they don't understand, I'm still trying to read and see but it's hard, I can't figure out everything. But that's actually the reason why I want to study more about Islam. The good place actually.

In this part of interview Asnate confirms that she is afraid of being placed in Indonesia since Indonesia is a moeslem country. This is very matterful since she worries if the moeslem do not understand. The statement do not understand here can be interpreted as moeslem a group of people who cannot build tolerancy towards other religious belief. The fear of being alone is also represented here by Asnate that this is her very first time to visit Indonesia. She might read a lot about Indonesia within the religious and tribal conflicts, thus she is worrying about her safety.

The statement of Asnate also portrays the idea of stereotype. As explained before that stereotype is broader term commonly used to refer to negative and positive judgments made about individuals based on any observable or believed group membership. In this case Asnate makes a negative judgement for believed group, moeslem. That moeslem is hard to voluntarily understand her culture and her belief as christian. Another form of stereotype from Asnate found in another statement,

A: Yes..Yea, me too. Also about relationship, male and female, again different. First about the dating, here for me when a boy ask me out, okay, it's just being friends. Not to say I like you.

I: (I get confuse for awhile) So when man asks me to go out means he likes me? 
A: Here. But there, I have friends, boys, he asks me to go out, that's just a dinner, not a date. And then how open the relationship are. It seems in all Europe of course, we are kissing in open area.

I: Is it like PDA? Public Display Affection?

A: Yea

I: Here you can't do that

The statement shows a strong stereotype that Indoneisan people are close in showing their relationship. The politeness is upheld strongly. No body is kissing or hugging in the public. Relationship is conceived as taboo in Indonesia. Indonesia,

Similar statements also shown by Yolanda regarding to the relationship in

I: What about the relationship?

$Y$ : You mean the casual relationship? Between male and female?

I: Yea

$Y:$ (pause for quite long and her friend, Vagi helps her to answer) In kosan in Jogja there is "laki-laki tidak boleh masuk". In Papua New Guenea it is different. They can masuk to kamar but the you cannot sleep there.

Anxiety is also haunted in Sainik's first prediction towards Jogja. It is still about moeslem, but in the different reason. If Asnate is afraid of moeslem because she thinks that moeslem is intollerant, Sainik who is from India find it is difficult to see people eat beef. It is commonly known that Hindi is not allowed to eat beef, because cow is the holy animal in India.

I : Yea.it's easy and healthy. So now, what comes to your mind before you go to Jogja?

$S$ : Indonesia.. at that time I was afraid because here is lots of Moeslem and India is lots of Hindu. My religion is Hindu and India is $80 \%$ Hindu and $14 \%$ moeslem $2 \%$ buddhist and the rest is variative. So at that time I takut to behaviour in this state.

The statement made by Sainik also shows that he is afraid because he does not know what is the best proper behavior he must do when he interacts with the country with $85 \%$ moeslem. The number of percentage also shows that Sainik has done at least a simple research about how many people with different religious belief he should be made friend. 
The symptoms of culture shocks that are found in these three the foreign students are criticism toward new country. The first criticism is about the profesionalism of the institution that give them scholarship. Asnate has a strong criticism to the CERTAIN OFFICIAL DEPARTMENTS for she is let to be alone and hang on weeks in Jakarta.

A: No! Because when I apply there's a comment that I have to be here in the very beginning of August.

I: Oh, Isee

A: Like the embassy and ministry and all about that. So you have to be here. So I came here, I came here actually in Indonesia was already in the 3rd of August. But, nobody picked me up like Darmasiswa was like they don't care that we are here. I called them like guys I'm here, why not nobody's in the airport? Oh really? There's no body?!Hmm..there should be somebody in the airport who look for. And I'm looking for an hour, for that somebody, but nobody. So I stay one week in Jakarta waiting for somebody, when somebody will say that ok, we're ready for you. And then pick you and take you to Jogja.

I: So you have to wait for a week in Jakarta before go to Jogja?

A: Yea..so I was calling everyday to Darmasiswa when can I come to the August? I wont to stand in Jakarta that long.

The statements strongly criticize how bad the profesionalism of certain official departments in the point of accomodation and giving ensurement to her as a western person, who is afraid of being in Indonesia. The same criticism about institution profesionalism is delivered by Yolanda, especially in the form of transportation terms.

Y: Yea, going to Jogja by train

I: O..bytrain, is it interesting?

$Y$ : (Laughing) very long and uncomfortable trip.

$I$ : A..very long and uncomfortable.so where do you stay right now in Jogja? 
Another type of culture shock symptoms is depression. Sainik is the only one in this research who states his depression about food. It is commnoly known that food is the primal necesity of human being. Sainik as a Hindi can only eat chicken and ikan in Jogja. The thing goes worse when he actually wants to cook by himself but he has no kitchen. Indonesian culture does not ask male to cook, that is why there is no kitchen provided there.

S: Yea...sure different. Beause here is a moeslem country. 85\% people are moeslem and India is $88 \%$ Hindu. So the religion is very different. You know it right? Here my problem is makan. Because in Indonesia people consume cows. I am very afraid to eat meat. If I go to any restaurant I should ask what is this? Because I can't eat sapi. So after thae seller say it is not sapi, it is chicken, I will eat.

I: So you can just eat chicken?

S: Yea, chicken and ikan.

I: What about pork? Is that allowed?

$S$ : You can stay in the same house but different room. For example we stay in a house that has four room, I stay in room A and my girlfriend stay in room B. In each of room we have kitchen. In Indonesia, in Jogja, only female boarding house has kitchen. Male no kitchen.

I: Yea..man usually buy meal in warung.

These all statements have genuinely depicted the forms and symptoms of culture shocks for foerign students of Yogyakarta.

\section{HOW THE FOREIGN FRESHMEN DEAL WITH THEIR CULTURE SHOCK.}

Based on the interviews, all of three fereign students choose to compromize with the cultural differences and keep trying to adapt as best as they can. The statement from Asnate that she has read a lot of things to discover the idea of moeslem, the statements of Sainik who says that he loves stay in Jogja because people are very helpful, and the statement of Yolanda that she wants to keep learning bahasa Indonesia in order to be able to make friends, closer than today. 
$Y$ : Maybe because the language. We just say hi, bye, smile..

I: yea.. it's the universal language

$Y$ : Right. Universal language. We want to learn more bahasa indonesia so we can soon make friends.

I: Have you ever had a problem in Jogja?

I: What do you afraid of?

A: Mmm...that they don't understand, I'm still trying to read and see but it's hard, I can't figure out everything. But that's actually the reason why I want to study more about Islam. The good place actually.

The three students are good example of culture participant. They have understood that they will live in a country which they know it might be risky to live there. But they prefer to try as best as possible to argue with the cultural differences because they know that basically, Indonesian people are sweet, friendly and helpful.

\section{CONCLUSION}

Based on the discussion above, it is found that the forms of culture shock in the foreign students in Yogyakarta are anxiety and stereotype of Moeslem, and the symptoms of culture shock are critisizing the new country and depression. However, the the foreign students tend to be tollerant and adaptable towards the cultural differences and strive to adapt to the new country culture.

\section{REFERENCES}

Chandra, B. \& S. Mahajan. 2007. Composite Culture in Multicultural Society. New Delhi: PearsonLongman.

Coulmas, F. 2003. The Handbook of Linguistics. New York: Blackwell. Jandt, F. E. 2004. An Introduction to Intercultural Communication. California: Sage Publications, Inc. 
Pinto, D. 2000. Intercultural Communication: A ThreeStep Method for Dealing with Differences. Leuven: Garant Publisher.

Samovar, L. A. \& R. E. Porter. 1991. Communication Between Cultures. California: Wadsworth.

Singer, M. R. (1998). Perception and Identity in Intercultural Communication. Yarmouth, ME.: Intercultural Press.

Trudgill, P. 2006. Sociolinguistics: An International Handbook of the Science of Language and Society. Berlin: Walter de Gruyter GmbH \& Co.

Wardaugh, R. 2006. An Introduction to Sociolinguistics. New York: Basil Blackwell. 